\title{
Psychometric Validation of the Short Form of the Smoking Consequences Questionnaire (S-SCQ) for Brazil
}

\author{
Validação Psicométrica do Short Form of the Smoking \\ Consequences Questionnaire (S-SCQ) a um contexto brasileiro
}

Marília Silva de Souza ${ }^{1}$

Jaciana Marlova Gonçalves Araújo ${ }^{2}$

Luciano Dias de Mattos Souza ${ }^{1}$

${ }^{1}$ Programa de PósGraduação em Saúde e Comportamento, Universidade Católica de Pelotas. R. Gonçalves Chaves 373, Centro. 96015-560 Pelotas RS Brasil. marilia-ss@hotmail.com ${ }^{2}$ Pró-Reitoria de Assuntos Estudantis, Universidade Federal do Rio Grande. Rio Grande RS Brasil

\begin{abstract}
Smoking accounts for 24\% of deaths in the general population and is also the factor that explains the biggest amount of years of life lost. It is important to understand the expectations regarding smoking behavior. The present study aimed to validate the Short Form of the Smoking Consequences Questionnaire (S-SCQ) for a Brazilian version. The Researchers did the process of semantic adaptation to language and national context. The S-SCQ was applied in a sample of 129 people. The next step was to perform psychometric analyses for the set of 21 items. Exploratory Factor Analysis, with pairwise treatment for missing cases, was used to achieve construct validity. To carry out Factor Analysis, the method of Principal Component Analysis (PCA) was used initially. Afterwards, Principal Axis Factoring (PAF) using Varimax rotation with Kaiser normalization was applied. The reliability of the total scale (21 items) showed a Cronbach alpha index of 0.851 and a 0.870 Lambda2 of Gutmann. Quite satisfactory rates were also observed in the subscales. Similarly, the item-overall correlation values also confirmed the scale's good reliability indices.

Key words Brazil, Smoking, Psychometrics, Validation studies
\end{abstract}

Resumo Fumar representa 24\% das mortes na população geral, sendo o fator que explica o maior número de anos de vida perdidos. É importante compreender as expectativas relacionadas ao comportamento de fumar. O presente estudo teve por objetivo validar o instrumento Short Form of the Smoking Consequences Questionnaire (S-SCQ) para uma versão brasileira. Após o processo de adaptação semântica para o idioma e o contexto nacional, o S-SCQ foi aplicado numa amostra de 129 pessoas. No passo seguinte, foram realizadas análises psicométricas para o conjunto de 21 itens. Os dados foram submetidos à prova de validade de construto por meio de Análise Fatorial Exploratória, com tratamento "pairwise" para casos omissos. Para proceder a Análise Fatorial se utilizou inicialmente o método da Análise dos Componentes Principais (ACP). Após, foi feita a Fatoração dos Eixos Principais (FEP) utilizando rotação Varimax com normalização de Kaiser. A fidedignidade da escala total (com 21 itens) apresentou indice alfa de Cronbach 0,851 e Lambda 2 de Gutmann 0,870. Indices bastante satisfatórios foram observados também nas subescalas. No mesmo sentido, os valores de correlação item-total também confirmaram os bons indices de fidedignidade da escala.

Palavras-chave Brasil, Tabagismo, Psicometria, Estudos de validação 


\section{Introduction}

Smoking is the main cause of preventable death in the world ${ }^{1}$. Smoking accounts for $24 \%$ of deaths in the general population and is also the factor that explains the biggest amount of years of life lost ${ }^{2}$. Even so, it is estimated that approximately one third of the global population are smokers ${ }^{1}$.

The main obstacle to smoking cessation is nicotine dependence. However, other

factors also difficult smoking cessation attempts. For example: weight gain ${ }^{3}$ and depressive symptoms onset ${ }^{4}$, both increasing the likelihood of relapse $e^{3,4}$. Furthermore, women smoke to women smoke to manage mood and relieve stress ${ }^{4}$.

Smoking cessation is a priority behavior for the prevention of diseases attributable to nicotine abuse ${ }^{5}$. For smoking cessation, three approaches are presented: attempting to stop smoking, planning or intention to quit smoking and health professional's recommendation for cessation ${ }^{6}$.

Expectations regarding the results of smoking and beliefs about the positive and

negative consequences of using can both enhance smoking behavior and difficult cessation ${ }^{7}$. Both expectations regarding consequences are part of influential and determinant theoretical models of drug use motivation ${ }^{8-12}$.

There are well-documented racial and ethnic differences between whites and racial minorities that influence the prevalence of smoking, standards and cessation, as well as use consequenc$\mathrm{es}^{13,14}$. Research among minority populations in the United States is an important priority for future findings ${ }^{15,16}$.

Most of the research on expectations of smoking results have been conducted using the Smoking Consequences Questionnaire - SCQ ${ }^{17}$. Since the SCQ was introduced, some versions have been developed and validated according to specific populations ${ }^{7,18-21}$. However, there is still no version adapted to the national context of Brazil. The SCQ has a short version consisting of 21 items - Short Form of the Smoking Consequences Questionnaire (S-SCQ) ${ }^{22}$ - that represents the four original SCQ factors and has demonstrated reliability and validity, being highly correlated with the complete range ${ }^{23}$.

Positive expectations facilitate drug use, in addition to contributing to relapse. Already negative expectations contribute to better outcomes in the cessation $^{24}$, showing greater health knowledge ${ }^{19}$. These expectations are relevant for explaining smoking behavior. Positive Reinforcement (PR) refers to expectations related to the sensory satisfaction of smoking. Negative Reinforcement (NR) refers to coping expectations and negative emotion regulation through smoking. Negative Consequences (NC) refer to expectations related to predicting little success in the cessation ${ }^{17}$.

Therefore, it is important to understand the expectations related to smoking behavior. Considering the lack of scales that help the understanding of smoking behavior in the national context, the present study aimed to evaluate the semantic relevance and psychometric quality of the items, as well as the execution and functionality of the S-SCQ for a Brazilian version, calling it the Short Form Smoking Consequences Questionnaire - Brazilian version (S-SCQ).

\section{Methods}

The study was approved by the research ethics committee of Universidade Católica de Pelotas. Written informed consent was obtained from all participants.

The semantic validation was performed through four steps: semantic analysis;

conceptual adequacy; operational adaptation and psychometric analysis.

\section{Semantic analysis}

The first step was the translation from English to the language of the target population, Brazilian Portuguese, by a psychologist with expertise in English language and knowledge of the subject (smoking). In the second step, a reverse-translation to the original language was done by a bilingual physical educator. A second version of the language in Portuguese was performed by another psychologist with knowledge of English and knowledge of the subject (smoking). The third stage was the analysis of the concordance of the versions by a group of experts. The group examined the adequacy of the terms.

\section{Conceptual adequacy}

The same group of experts performed the analysis of which items of the version corresponded for measuring smoking results expectations, compared to the original version. That is, if the items were appropriate for the factors that they are proposed to measure in the original scale (Chart 1). 
Chart 1. Translation process and retranslation of Smoking Consequences Questionnaires instrument (SCQ).

\begin{tabular}{|c|c|c|c|}
\hline Original version & Translation (Version 1) & Version 2 & Version 3 \\
\hline $\begin{array}{l}\text { Factor 1: Negative } \\
\text { Consequences } \\
\text { 1. Smoking is to take } \\
\text { years off my life. } \\
\text { 2. Smoking is a hazard to } \\
\text { my health } \\
\text { 3. The more I smoke; the } \\
\text { more I risk my health. } \\
\text { 4. By smoking I am at } \\
\text { risk of heart disease and } \\
\text { lung cancer. }\end{array}$ & $\begin{array}{l}\text { Fator 1: Consequências } \\
\text { negativas } \\
\text { 1. Fumar é tirar anos da } \\
\text { minha vida. } \\
\text { 2. Fumar é perigoso } \\
\text { para a minha saúde. } \\
\text { 3. Quanto mais eu } \\
\text { fumo, mais eu arrisco } \\
\text { minha saúde. } \\
\text { 4. Ao fumar eu corro } \\
\text { risco de ter doenças } \\
\text { cardíacas e câncer de } \\
\text { pulmão. }\end{array}$ & $\begin{array}{l}\text { Fator 1: Consequências } \\
\text { Negativas } \\
\text { 1. Fumar significa perder } \\
\text { anos da minha vida. } \\
\text { 2. Fumar é prejudicial à } \\
\text { minha saúde. } \\
\text { 3. Quanto mais eu fumo, } \\
\text { maior é o risco para minha } \\
\text { saúde. } \\
\text { 4. Ao fumar, eu estou } \\
\text { em risco de desenvolver } \\
\text { doenças cardíacas e câncer } \\
\text { de pulmão. }\end{array}$ & $\begin{array}{l}\text { Fator 1: Consequências } \\
\text { Negativas } \\
\text { 1. Fumar significa perder } \\
\text { anos da minha vida. } \\
\text { 2. Fumar é prejudicial à } \\
\text { minha saúde. } \\
\text { 3. Quanto mais eu fumo, } \\
\text { mais eu arrisco minha } \\
\text { saúde. } \\
\text { 4. Ao fumar, eu estou } \\
\text { em risco de desenvolver } \\
\text { doenças cardíacas e } \\
\text { câncer de pulmão. }\end{array}$ \\
\hline $\begin{array}{l}\text { Factor 2: Positive } \\
\text { Reinforcement } \\
\text { 1. Cigarettes taste nice. } \\
\text { 2. I enjoy the taste } \\
\text { sensations while smoking. } \\
\text { 3. When I smoke, the } \\
\text { flavor is pleasant. } \\
\text { 4. I will appreciate the } \\
\text { flavor of a cigarette. } \\
\text { 5. I enjoy feeling the } \\
\text { cigarette in my tongue } \\
\text { and lips. }\end{array}$ & $\begin{array}{l}\text { Fator 2: Reforço positivo } \\
\text { 1. Cigarros têm um } \\
\text { gosto bom. } \\
\text { 2. Eu gosto das } \\
\text { sensações gustativas } \\
\text { enquanto fumo. } \\
\text { 3. Quando eu fumo, o } \\
\text { sabor é agradável. } \\
\text { 4. Vou apreciar o sabor } \\
\text { de um cigarro. } \\
\text { 5. Gosto de sentir o } \\
\text { cigarro na minha língua } \\
\text { e lábios. }\end{array}$ & $\begin{array}{l}\text { Fator 2: Reforço Positivo } \\
\text { 1. Cigarros são saborosos. } \\
\text { 2. Eu gosto das sensações } \\
\text { de sabor ao fumar. } \\
\text { 3. Quando fumo, o sabor é } \\
\text { agradável. } \\
\text { 4. Eu irei apreciar o sabor } \\
\text { de um cigarro. } \\
\text { 5. Eu gosto de sentir o } \\
\text { cigarro em minha língua e } \\
\text { em meus lábios. }\end{array}$ & $\begin{array}{l}\text { Fator 2: Reforço Positivo } \\
\text { 1. Cigarros têm um } \\
\text { gosto bom. } \\
\text { 2. Eu gosto das sensações } \\
\text { de sabor enquanto fumo. } \\
\text { 3. Quando eu fumo, o } \\
\text { sabor é agradável. } \\
\text { 4. Eu irei apreciar o } \\
\text { sabor de um cigarro. } \\
\text { 5. Eu gosto de sentir o } \\
\text { cigarro em minha língua } \\
\text { e em meus lábios. }\end{array}$ \\
\hline $\begin{array}{l}\text { Factor 3: Negative } \\
\text { Reinforcement } \\
\text { 1. When I am angry a } \\
\text { cigarette can calm me } \\
\text { down. } \\
\text { 2. Cigarettes help me deal } \\
\text { with my anger. } \\
\text { 3. Cigarettes help me deal } \\
\text { with anxiety or worry. } \\
\text { 4. Smoking calms me } \\
\text { down when I am feeling } \\
\text { nervous. } \\
\text { 5. Smoking helps me deal } \\
\text { with depression. } \\
\text { 6. Cigarettes help me } \\
\text { reduce or handle tension. } \\
\text { 7. Cigarettes help me } \\
\text { overcome when I am } \\
\text { upset with someone. } \\
\text { 8. Smoking helps me } \\
\text { control my weight. }\end{array}$ & $\begin{array}{l}\text { Fator 3: Reforço negativo } \\
\text { 1. Quando eu estou } \\
\text { com raiva um cigarro } \\
\text { pode me acalmar } \\
\text { 2. Cigarros me ajudam } \\
\text { a lidar com a raiva } \\
\text { 3. Cigarros me ajudam } \\
\text { a lidar com a ansiedade } \\
\text { ou preocupação } \\
\text { 4. Fumar me acalma } \\
\text { quando eu me sinto } \\
\text { nervoso } \\
\text { 5. Fumar me ajuda a } \\
\text { lidar com a depressão } \\
\text { 6. Cigarros me ajudam } \\
\text { a reduzir ou lidar com a } \\
\text { tensão } \\
\text { 7. O cigarro me ajuda } \\
\text { a superar quando estou } \\
\text { chateada com alguém. }\end{array}$ & $\begin{array}{l}\text { Fator 3: Reforço Negativo } \\
\text { 1. Um cigarro me acalma } \\
\text { quando estou irritado. } \\
\text { 2. Cigarros me ajudam a } \\
\text { lidar com minha raiva. } \\
\text { 3. Cigarros me ajudam } \\
\text { a lidar com ansiedade ou } \\
\text { preocupações. } \\
\text { 4. Fumar me acalma } \\
\text { quando estou me sentindo } \\
\text { nervoso. } \\
\text { 5. Fumar me ajuda a lidar } \\
\text { com a depressão. } \\
\text { 6. Cigarros me ajudam } \\
\text { a reduzir ou lidar com } \\
\text { tensões. } \\
\text { 7. Cigarros me ajudam } \\
\text { a superar quando estou } \\
\text { chateado com alguém. }\end{array}$ & $\begin{array}{l}\text { Fator 3: Reforço Negativo } \\
\text { 1. Quando eu estou com } \\
\text { raiva um cigarro pode } \\
\text { me acalmar. } \\
\text { 2. Cigarros me ajudam a } \\
\text { lidar com minha raiva. } \\
\text { 3. Cigarros me ajudam a } \\
\text { lidar com a ansiedade ou } \\
\text { preocupações. } \\
\text { 4. Fumar me acalma } \\
\text { quando eu me sinto } \\
\text { nervoso. } \\
\text { 5. Fumar me ajuda a } \\
\text { lidar com a depressão. } \\
\text { 6. Cigarros me ajudam } \\
\text { a reduzir ou lidar com a } \\
\text { tensão. } \\
\text { 7. Cigarros me ajudam } \\
\text { a superar quando estou } \\
\text { chateado com alguém. }\end{array}$ \\
\hline
\end{tabular}

it continues

\section{Operational adaptation}

In order to assess the semantic characteristics of the test version and verify the operational ad- aptation of the instrument, the author (M.S.S) conducted 10 individual interviews with smokers in a Psychosocial Care Center (CAPS) specialized in Alcohol and Drug Care. At the end of the in- 
Chart 1. Translation process and retranslation of Smoking Consequences Questionnaires instrument (SCQ).

\begin{tabular}{|c|c|c|c|}
\hline Original version & Translation (Version 1) & Version 2 & Version 3 \\
\hline $\begin{array}{l}\text { Factor 4: Appetite-Weight } \\
\text { Control } \\
\text { 1. Smoking keeps my } \\
\text { weight down. } \\
\text { 2. Cigarettes help me } \\
\text { keep my weight and not } \\
\text { eat more than I should. } \\
\text { 3. Smoking controls my } \\
\text { appetite. } \\
\text { 4. Cigarettes help me } \\
\text { control my weight and not } \\
\text { overeat. }\end{array}$ & $\begin{array}{l}\text { Fator 4: Controle do } \\
\text { apetite e do peso } \\
\text { 1. Fumar me ajuda a } \\
\text { controlar meu peso. } \\
\text { 2. Fumar mantém meu } \\
\text { peso baixo. } \\
\text { 3. Cigarros ajudam a } \\
\text { me manter e não comer } \\
\text { mais do que deveria. } \\
\text { 4. Fumar controla meu } \\
\text { apetite. } \\
\text { 5. Cigarros ajudam a } \\
\text { me manter e não comer } \\
\text { em excesso. }\end{array}$ & $\begin{array}{l}\text { Fator 4: Controle de Peso e } \\
\text { Apetite } \\
\text { 1. Fumar me ajuda a } \\
\text { controlar meu peso. } \\
\text { 2. Fumar mantém meu } \\
\text { peso baixo. } \\
\text { 3. Cigarros me ajudam } \\
\text { a manter o peso e a não } \\
\text { comer mais do que deveria. } \\
\text { 4. Fumar controla meu } \\
\text { apetite. Cigarros me ajudam } \\
\text { a controlar meu peso e não } \\
\text { comer demais. }\end{array}$ & $\begin{array}{l}\text { Fator 4: Controle de Peso } \\
\text { e Apetite } \\
\text { 1. Fumar me ajuda a } \\
\text { controlar meu peso. } \\
\text { 2. Fumar mantém meu } \\
\text { peso baixo. } \\
\text { 3. Cigarros me ajudam } \\
\text { a manter o peso e a } \\
\text { não comer mais do que } \\
\text { deveria. } \\
\text { 4. Fumar controla meu } \\
\text { apetite. } \\
\text { 5. Cigarros me ajudam a } \\
\text { controlar meu peso e não } \\
\text { comer demais. }\end{array}$ \\
\hline
\end{tabular}

terviews, adjustments were made by the authors in order to improve the target population's understanding of the instrument.

After this, the Brazilian version of the S-SCQ was applied in a convenience sample of 129 people. The sample size sought to meet the psychometric criteria of at least 5 subjects per item measured by the scale ${ }^{25}$. Participants were captured from two CAPSs (in the cities of Pelotas and Canguçu - Rio Grande do Sul), a CAPS - alcohol and other drugs (Canguçu), a Primary Care Unit (UBS) linked to the Catholic University of Pelotas (UCPel) and also in areas with a large flow of people that would allow for the representation of the general population (bus stops, near hospitals and universities). The exclusion criteria were physical incapacity or inability to understand the questionnaire or having participated in the first 10 interviews. The only inclusion criteria was aged 18 or more. The instrument was kept as an individual self-report questionnaire during both pre-test and this stage, as recommended by the original version, just like the material's form of presentation (printed).

\section{Psychometric analysis}

Psychometric analyses were performed for the set of 21 items. Exploratory Factor Analysis of the scale was performed in order to determine if the theoretical factors were represented by the instrument in the test version and how much of the data variance could be explained by the factors model. All the procedures adopted in the analysis are indicated by Pasquali ${ }^{25}$. The data were submitted for the construct validity of the test by means of Exploratory Factor Analysis, with pairwise treatment for missing cases.

To carry out Factor Analysis, the method of Principal Component Analysis (PCA) was initially used. Concerning the indicators for component extraction, presence of eigenvalues above 1 was used as the criterion in the analysis with 21 items. Afterward, Principal Axis Factoring (PAF) using Varimax rotation with Kaiser normalization was performed. In all analyses, factor loads with a value below 0.30 were not considered ${ }^{25}$. Reliability was investigated through the method of internal consistency (Cronbach's Alpha and Lambda2 by Guttman). Item-overall correlation coefficients were also observed in order to verify the consistency of each item in relation to overall score.

\section{Results}

When assessing the semantic equivalence of the S-SCQ instrument between the original and translated versions, it was possible to identify the equivalence of instrument items. All items match their respective original factors.

After application of the instrument with 10 smokers of a convenience sample, few terms have been flagged as not fully understood. By identifying these, it is emphasized that five words were changed as a result of the analysis of understanding problems and doubts of respondents during the course of the questionnaire. 
The replacement of the word "prejudicial" (item 2) by the word "perigoso" emphasized how smoking behavior presents a danger to the health of the subject. The change of the word "sabor" to "gosto" stressed that it is possible to distinguish the sensation (palate) produced by smoking (item 7). In section 6, it was chosen not to change the word "sabor", as the word "gostar" in the first person singular, used in translations and supported by the judges, made the item confusing. In item 8 , the amendment of "apreciar" to "aproveitar" highlighted the act of liking and appreciating the flavor/taste of a cigarette. Changing the word "depressão" to "tristeza" in item 14 allowed greater understanding that it was the state of feeling (being sad) and not of pathology. In item 15, modifying "tensão" to "estresse" allowed better definition of the state of being tense or under pressure. After these changes, the final version was designed, shown in the Figure 1. These changes aimed to make the sentences clearer for respondents.

The sample was composed of 129 people, mostly females $(58.1 \%)$, with a mean age of 43 years $( \pm 14.23)$. In education, the most frequent category was up to 8 years of education (48.1\%), and $9.3 \%$ had completed higher education. Principal Component Analysis (PCA) showed satisfactory initial commonalities, high significance in the Barlett test $(\mathrm{p}<0,001)$ and a Kaiser-Meyer-Olkin (KMO) sample adequacy ratio of 0.81 (ideally greater than 0.60 ). Therefore, the analysis indicated the data could be submitted for factor analysis.

Four components had eigenvalues greater than 1 in the initial analysis and principal axis factoring confirmed the existence of four components. The percentage of variance explained in each of the factors is shown in Table 1 . The factor loadings of the items ranged between 0.60 and 0.90 , with the exception of a complex item that presented a load of 0.306 in a factor that was not its origin. When it comes to proceeding with the factor analysis without the complex item, both in the analysis that considered the scale as a whole and in relation to its origin factor, no results that justified its exclusion from the scale were obtained, so the item was kept. The reliability of the total scale (21 items) showed a Cronbach alpha index of 0.851 and a 0.870 Lambda 2 of Gutmann. Regarding this, according to Table 2, quite satisfactory rates were also observed in the subscales. Similarly, the item-overall correlation values also confirmed the scale's good reliability indices.

\section{Discussion}

The purpose of this study was to adapt a scale that measures the expectations of smoking results for use in Brazilian context. The S-SCQ was chosen because it has already been the subject of some studies that have shown satisfactory psychometric qualities in other countries ${ }^{18,19}$ and it is a short scale, capable of use in research and treatment sites. The instrument's different validity parameters were explored to improve the potential results and interpretations that it would provide. In this adaptation, some modifications were necessary. A small reformulation semantics was required and some terms have been replaced by synonyms easy to understand. Only one complex item was observed during the validation process. Item 6 of the original version presented factor loading for its origin domain (PR) and a lower load, but still above the 0.30 criterion, for the Negative Reinforcement component in its adapted version. However, this psychometric feature may be the result of the scale's semantic adaptation. The biggest factor loading of the item corresponded to its origin domain and no data were obtained to justify its removal from the scale. Therefore, we believe that this feature does not interfere in the measurement of the constructs in question.

Regarding the factor analysis data, results show a fairly consistent structure and reliability regarding the original version and theory that supports the instrument. In the study of the construction and validation of the S-SCQ, the theoretical model of four factors was evidenced, featuring a high coefficient (0.93), which is a slight reduction compared to the full scale $(0.93)^{17}$.

The convenience sample was allocated in places that provide specific public health services for treatment of people who use psychoactive substances and sites that offer treatment for mental disorders, precisely because individuals with these profiles are referenced in the literature as those who have higher prevalence of smoking $^{26,27}$. Similarly, public places with great movement flow of people were chosen (bus stops, near hospitals and universities) to try to count with greater variability of sociodemographic characteristics and, therefore, have greater representation, even in a non-random sample.

The participation of the general population is an advantage because it allows to determine demographic effects on variables, providing more adequate evidence of the instrument's access and the efficiency of the information proposals. 
Figure 1. Brazilian version of the Smoking Consequences Questionnaires instrument (SCQ).

Abaixo há uma lista de declarações sobre o fumo. Cada declaração contém uma possível consequência do fumo. Para cada uma das afirmações abaixo, por favor, marque o quão provável ou improvável você acredita que cada consequência tem para você quando você fuma. Se o resultado parece pouco provável, circule um número de 0 a 4 . Se a consequência parece provável, circule um número de 5 a 9. Isto é, se você acredita que uma consequência nunca vai acontecer, círculo 0 , se você acredita que uma consequência pode acontecer a cada vez que você fuma, círculo 9.

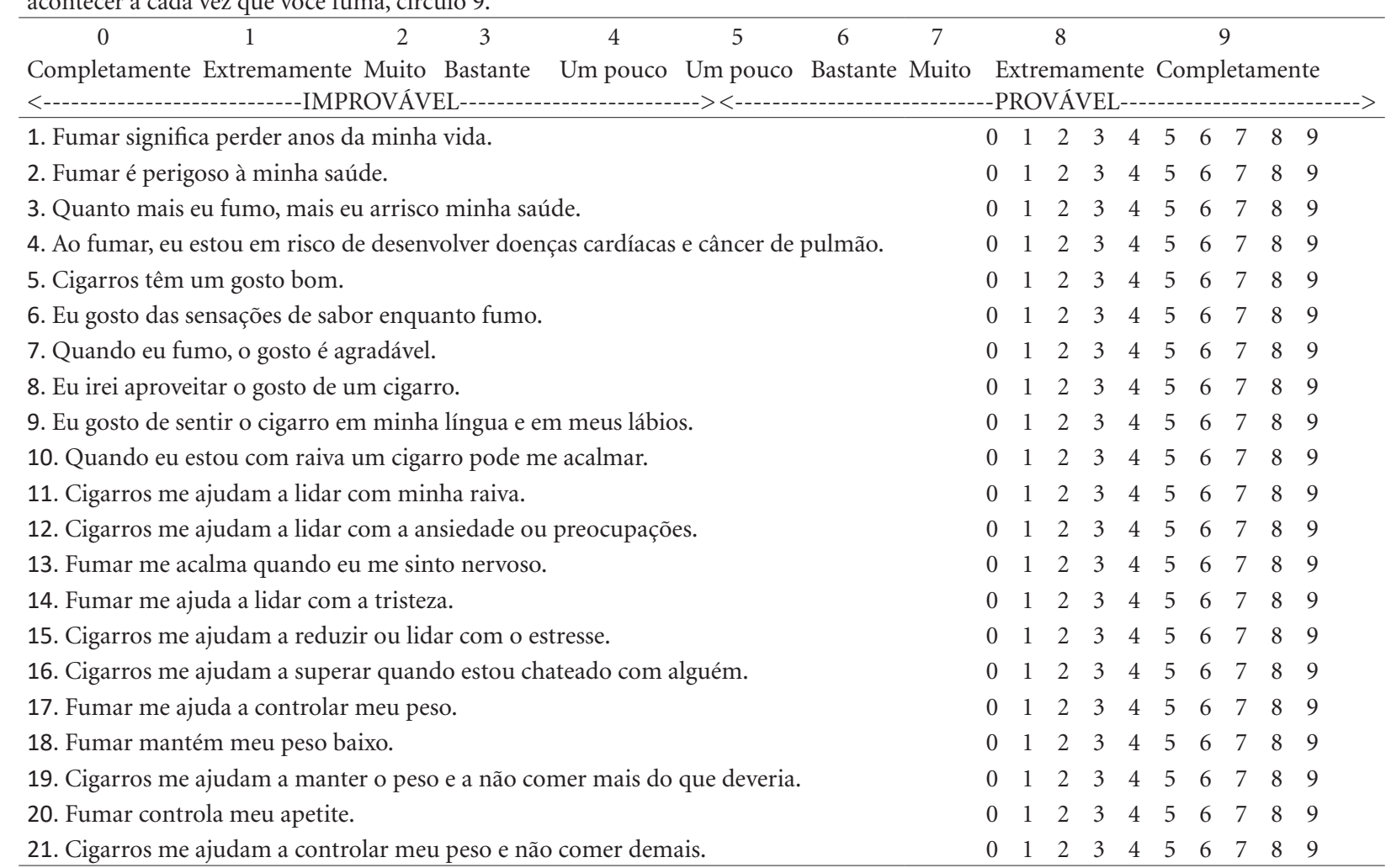

Given the characteristics of the sample investigated, only $9.3 \%$ have higher level of education completed or more. The schooling of the sample is low when compared with the general population, showing that the lowly-educated population's understanding of this instrument is consistent. The instrument's administration features do not seem to have influenced the understanding of it. Instrument application was done by the respondents themselves. The instrument, as in the original version, is self-administered. International studies also followed the original version as their application form ${ }^{20}$.

Based on the results of the validation, we can note that using the S-SCQ provides understanding of smoking behavior habits and, as such, helps to formulate different treatment strategies according to different expectations of the results of smoking.

Being a short and easy to use instrument, it can be a first option to screen tobacco use and, especially, to understand smoking behavior and beliefs about the consequences of the results of smoking. It is an objective way to obtain information without the need for evaluation essentially subjective to elucidate assumptions that are required for intervention. Data from the application of the S-SCQ are valuable for comparing the consequences of smoking between specific characterization groups. The use of this instrument can help in planning the intervention process and its approaches, in order to reach the phase of abstinence. Understanding the expectations of their behavior related to tobacco smoking gives us basis to strategize behavioral interventions consistent with their reality, assuming that this behavior is anchored in the theoretical basis of Bandura' $\mathrm{s}^{28}$ social learning, which refers to substance use as a learned behavior, set off and maintained by events and emotions, which can be modified.

This is the first validated Brazilian-version instrument of smoking consequences. 
Table 1. Principal Component Analysis, variance explained in each of the factors of the Short Form of the Smoking Consequences Questionnaire (S-SCQ) and reliability of the instrument.

\begin{tabular}{|c|c|c|c|c|c|}
\hline \multirow[b]{2}{*}{ Items } & \multicolumn{4}{|c|}{ Factors } & \multirow{2}{*}{$\begin{array}{c}\text { Item- } \\
\text { overall } \\
\text { correlation } \\
\quad(\mathbf{r})\end{array}$} \\
\hline & $\begin{array}{c}\text { Negative } \\
\text { Consequences }\end{array}$ & $\begin{array}{c}\text { Positive } \\
\text { Reinforcement }\end{array}$ & $\begin{array}{c}\text { Negative } \\
\text { Reinforcement }\end{array}$ & $\begin{array}{c}\text { Appetite } \\
\text { and Weight } \\
\text { Control }\end{array}$ & \\
\hline $\begin{array}{l}\text { 1. Fumar significa perder anos } \\
\text { da minha vida. }\end{array}$ & 0,664 & & & & 0,240 \\
\hline $\begin{array}{l}\text { 2. Fumar é perigoso à minha } \\
\text { saúde. }\end{array}$ & 0,867 & & & & 0,366 \\
\hline $\begin{array}{l}\text { 3. Quanto mais eu fumo, mais } \\
\text { eu arrisco minha saúde. }\end{array}$ & 0,821 & & & & 0,373 \\
\hline $\begin{array}{l}\text { 4. Ao fumar, eu estou em } \\
\text { risco de desenvolver doenças } \\
\text { cardíacas e câncer de pulmão. }\end{array}$ & 0,757 & & & & 0,302 \\
\hline 5. Cigarros têm um gosto bom. & & 0,675 & & & 0,250 \\
\hline $\begin{array}{l}\text { 6. Eu gosto das sensações de } \\
\text { sabor enquanto fumo. }\end{array}$ & & 0,616 & 0,306 & & 0,452 \\
\hline $\begin{array}{l}\text { 7. Quando eu fumo, o gosto é } \\
\text { agradável. }\end{array}$ & & 0,900 & & & 0,422 \\
\hline $\begin{array}{l}\text { 8. Eu irei aproveitar o gosto de } \\
\text { um cigarro. }\end{array}$ & & 0,803 & & & 0,413 \\
\hline $\begin{array}{l}\text { 9. Eu gosto de sentir o cigarro } \\
\text { em minha língua e em meus } \\
\text { lábios. }\end{array}$ & & 0,704 & & & 0,440 \\
\hline $\begin{array}{l}\text { 10. Quando eu estou com raiva } \\
\text { um cigarro pode me acalmar. }\end{array}$ & & & 0,689 & & 0,452 \\
\hline $\begin{array}{l}\text { 11. Cigarros me ajudam a lidar } \\
\text { com minha raiva. }\end{array}$ & & & 0,776 & & 0,444 \\
\hline $\begin{array}{l}\text { 12. Cigarros me ajudam a } \\
\text { lidar com a ansiedade ou } \\
\text { preocupações. }\end{array}$ & & & 0,827 & & 0,447 \\
\hline $\begin{array}{l}\text { 13. Fumar me acalma quando } \\
\text { eu me sinto nervoso. }\end{array}$ & & & 0,805 & & 0,486 \\
\hline $\begin{array}{l}\text { 14. Fumar me ajuda a lidar com } \\
\text { a tristeza. }\end{array}$ & & & 0,604 & & 0,498 \\
\hline $\begin{array}{l}\text { 15. Cigarros me ajudam a } \\
\text { reduzir ou lidar com o estresse. }\end{array}$ & & & 0,753 & & 0,591 \\
\hline $\begin{array}{l}\text { 16. Cigarros me ajudam a } \\
\text { superar quando estou chateado } \\
\text { com alguém. }\end{array}$ & & & 0,611 & & 0,527 \\
\hline $\begin{array}{l}\text { 17. Fumar me ajuda a controlar } \\
\text { meu peso. }\end{array}$ & & & & 0,775 & 0,392 \\
\hline $\begin{array}{l}\text { 18. Fumar mantém meu peso } \\
\text { baixo. }\end{array}$ & & & & 0,721 & 0,361 \\
\hline $\begin{array}{l}\text { 19. Cigarros me ajudam a } \\
\text { manter o peso e a não comer } \\
\text { mais do que deveria. }\end{array}$ & & & & 0,861 & 0,517 \\
\hline 20. Fumar controla meu apetite. & & & & 0,851 & 0,472 \\
\hline $\begin{array}{l}\text { 21. Cigarros me ajudam a } \\
\text { controlar meu peso e não comer } \\
\text { demais. }\end{array}$ & & & & 0,836 & 0,504 \\
\hline Eigenvalue & 2,223 & 3,047 & 5,554 & 3,491 & \\
\hline$\%$ of explained variance & 26,5 & 16,6 & 10,2 & 14,5 & \\
\hline Cronbach Alfa's & 0,865 & 0,863 & 0,888 & 0,907 & \\
\hline Lambda $_{2}$ & 0,866 & 0,867 & 0,892 & 0,908 & \\
\hline
\end{tabular}


Therefore, the contribution of this study lies in the dissemination of an instrument that can be widely and systematically used, and thus, support the planning of strategies for smoking cessation in primary care services or further Brazilian research on this field.

This study has limitations. First, expectancies were assessed only at one moment. Therefore, participants may have experienced changes in expectancies during the course of the tobacco use disorder. These changes may have influenced smoking behavior and cessation. The non-probabilistic process of sample selection prevents the generalization of the results found. Therefore, the present scale can be considered valid for populations with characteristics similar to those of the present study.

On the other hand, the validation of the S-SCQ scale presents important strengths. The results of the psychometric validation process were quite congruent with validation processes, of the same scale, for other languages and contexts. Therefore, the availability of a brief scale and easy application aligns the needs of the field of research on smoking especially for epidemiological studies in Public Health.

\section{Collaborations}

MS Souza - Substantial contributions to the conception and design of the work; acquisition, analysis, and interpretation of data for the work; Drafting the work and revising it critically for important intellectual content; Final approval of the version to be published. JMG Araújo - Substantial contributions to the acquisition, analysis, or interpretation of data for the work; Final approval of the version to be published. LDM Sou$\mathrm{za}$ - Substantial contributions to the conception and design of the work; Drafting the work and revising it critically for important intellectual content; Final approval of the version to be published. 


\section{References}

1. World Health Organization (WHO). [cited 2013 May 27]. Available in: http://www.who.int/topics/hiv_aids/ en/

2. Helleberg M, Afzal S, Kronborg G, Larsen CS, Pedersen G, Pedersen C, Gerstoft J, Nordestgaard BG, Obel N. Mortality Attributable to Smoking Among HIV-1 Infected Individuals: A Nationwide, Population-Based Cohort Study. Clin Infect Dis 2013; 56(5):727-734.

3. Ward KD, Klesges RC, Zbikowski SM, Bliss RE, Garvey AJ. Gender differences in the outcome of an unaided smoking cessation attempt. Addict Behav 1997; 22:521533.

4. Brasil. Ministério da Saúde (MS). Portal da Saúde. [cited 2013 May 27]. Available in: http://portalsaude. saude.gov.br/portalsaude/index.html

5. Feng G, Jiang Y, Li Q, Yong H-H, Elton-Marshall T, Yang J, Li L, Sansone N, Fong GT. Individual-level factors associated with intentions to quit smoking among adult smokers in six cities of China: findings from the ITC China Survey. Tob Control 2010; 19(Supl. 2):i6-11.

6. Instituto Nacional de Câncer (INCA). Pesquisa nacional por amostra de domicílios - tabagismo 2008. Rio de Janeiro: INCA; 2009.

7. Vidrine JI, Vidrine DJ, Costello TJ, Mazas C, Cofta-Woerpel L, Mejia LM, Wetter DW. The Smoking Consequences Questionnaire: Factor structure and predictive validity among Spanish-speaking Latino smokers in the United States. Nicotine Tob Res 2009; 11(11):12801288.

8. Baker TB, Morse E, Sherman JE. The motivation to use drugs: A psychobiological analysis of urges. Nebr Symp Motiv 1986; 34:257-323.

9. Goldman MS, Brown SA, Christensen BA. Expectancy theory: Thinking about drinking. In: Blane HT, Leonard KE, editors. Psychological theories of drinking and alcoholism. New York: Guilford Press; 1987. p. 181-226.

10. Marlatt GA, Gordon JR. Relapse prevention: Maintenance strategies in the treatment of addictive behaviors. New York: Guilford Press; 1985.

11. Niaura R, Goldstein M, Abrams D. A bioinformational systems perspective on tobacco dependence. Br J Addict 1991; 86(5):593-597.

12. Witkiewitz K, Marlatt GA. Relapse prevention for alcohol and drug problems: That was Zen, this is Tao. Am Psychol 2004; 59(4):224-235.

13. Centers for Disease Control and Prevention (CDC). Cigarette smoking among adults - United States, 2007. Morbidity and Mortality Weekly Report 2008; 57:12211226.

14. U.S. Department of Health and Human Services (USDHHS). Tobacco use among U.S. racial/ethnic minority groups. Atlanta: Public Health Service, Centers for Disease Control and Prevention, National Center for Chronic Disease Prevention and Health Promotion, Office on Smoking and Health; 1998.

15. Fiore MC, Bailey WC, Cohen SJ, Dorfman SF, Goldstein MG, Gritz ER, et al. Treating tobacco use and dependence: Clinical practice guideline. Rockville: U.S. Department of Health and Human Services, Public Health Service; 2000.

16. U.S. Department of Health and Human Services (USDHHS). Healthy people 2010. Washington: USDHHS; 2001.
17. Brandon TH, Baker TB. The Smoking Consequences Questionnaire: The subjective expected utility of smoking in college students. Psychol Assess 1991; 3(3):484-491.

18. Thomas JL, Bronars CA, Stewart DW, Okuyemi KS, Befort CA, Nazir N, Mayo MS, Jeffries SK, Ahluwalia JS. Psychometric properties of a Brief Smoking ConsequencesQuestionnaire for Adults (SCQ-A) among African American light smokers. Subst Abus 2009; 30(1):14-25.

19. Reig-Ferrer A, Cepeda-Benito. Smoking expectancies in smokers and never smokers: An examination of the smoking consequences questionnaire - Spanish. Addict Behav 2007; 32(7):1405-1415.

20. Buckley TC, Kamholz BW, Mozley SL, Gulliver SB, Holohan DR, Helstrom AW, Walsh K, Morissette SB, Kassel JD. A psychometric evaluation of the Smoking Consequence Questionnaire Adult in smokers with psychiatric conditions. Nicotine Tob Res 2005; 7(5):739-745.

21. Lewis-Esquerre JM, Rodrigue JR, Kahler CW. Development and validation of an adolescent smoking consequences questionnaire. Nicotine Tob Res 2005; 7(1):8190.

22. Myers MG, McCarthy DM, MacPherson, Brown AS. Constructing a Short Form of the Smoking Consequences Questionnaire With Adolescents and Young Adults. Psychol Assess 2003; 15(2):163-172.

23. Urbán R, Demetrovics Z. Smoking outcome expectancies: A multiple indicator and multiple cause (MIMIC) model. Addict Behav 2010; 35(6):632-635.

24. Stewart DW, Adams CE, Cano MA, Correa-Fernández V, Li Y, Waters DW, Wetter D, Vidrini JI. Associations Between Health Literacy and Established Predictors of Smoking Cessation. Am J Public Health 2013; 103(7):43-4a9.

25. Pasquali L. Análise fatorial para pesquisadores. Brasilia: LabPAM; 2005.

26. Lasser K, Boyd JW, Woolhandler S, Himmelstein DU, McCormick D, Bor DH. Smoking and mental illness: A population-based prevalence study. JAMA 2000; 284(20):2606-2610.

27. Buckley TC, Kamholz BW, Mozley SL, Gulliver SB, Holohan DR, Helstrom W, Walsh K, Morissette SB, Kasse JD. A psychometric evaluation of the Smoking Consequences Questionnaire-Adult in smokers with psychiatric conditions. Nicotine Tob Res 2005; 7(5):739-745.

28. Silva IF, Ferreira SL, Zanelatto NA. Terapia cognitivocomportamental aplicada ao tratamento de dependentes de nicotina. In: Zanelatto NA, Laranjeira R, organizadores. O tratamento da dependência química $e$ as terapias cognitivo-comportamentais: um guia para terapeutas. Porto Alegre: Artmed; 2013. p. 503-520.

Artigo apresentado em 07/04/2016

Aprovado em 25/11/2016

Versão final apresentada 27/11/2016 
